\title{
Квантовые сенсоры физических полей на ансамблях NV центров в алмазных наноструктурах
}

\author{
С.Н. Подлесный ${ }^{1}$, И.А. Карташов ${ }^{1}$, С.М. Тарков ${ }^{1}$, В.А. Володин ${ }^{1}$, В.П. Попов ${ }^{1}$, И.Н. Куприянов ${ }^{2}$, \\ Ю.Н. Пальянов ${ }^{2}$, А.А. Емельянов ${ }^{3}$, Н.И. Тимошенко ${ }^{3}$, А.К. Ребров ${ }^{3}$ \\ ${ }^{1}$ ФГБУН Институт физики полупроводников им. А.В. Ржсанова СО РАН \\ 630090, пр. ак. Лаврентьева 13, Новосибирск, Россия \\ ${ }^{2}$ ФГБУН Институт геологии и минералогии им. В.С. Соболева СО РАН, \\ 630090, пр. ак. Коптюга 3, Новосибирск, Россия \\ ${ }^{3}$ ФГБУН Институт теплофизики им. С.С. Кутателадзе СО РАН, \\ 630090, пр. ак. Лаврентьева 1, Новосибирск, Россия \\ тел.: +7(383)333-25-37, эл. почта: ророv@isp.nsc.ru
}

DOI 10.34077/RCSP2021-35

Предел обнаружения квантовых сенсоров на спинах пар азот-вакансия (NV) и их ансамблях в алмазе пропорционален времени дефазировки спинов $\mathrm{T}_{2}{ }^{*}$ и обратно пропорционален корню их концентрации. Однако $\mathrm{T}_{2}{ }^{*}$ зависит от спинов других дефектов и обычно $\mathrm{T}_{2}{ }^{*}<\mathrm{T}_{2}-$ времени спиновой релаксации на $\mathrm{NV}$ центрах. Причем экспериментально выполняется соотношение $\mathrm{T}_{2}{ }^{*}<<\mathrm{T}_{2}$ при теоретической величине $\mathrm{T}_{2} / \mathrm{T}_{2}{ }^{*} \approx 16$ за счет неспаренного электрона доноров $\mathrm{N}_{\mathrm{s}}{ }^{0}$ [1]. Важнейшей задачей является увеличение плотности NV центров при сохранении длительного времени спиновой когерентности [2]. Оно зависит как от качества специально разработанных синтетических кристаллов “квантового класса", так и от формирования ансамблей и гибкости метода химического осаждения из паровой фазы с помощью плазмы (CVD). Проблемой остается создание ансамблей в заданной области с контролем числа NV центров. Задача формирования ансамблей квантового класса была решена в ИФП, ИГМ и ИТФ СО РАН.

Ансамбли NV- центров создавались нами в $<111>$ пластинах алмаза типа IІа “горячей" имплантацией ионов азота $\mathrm{N}^{+}$и термообработкой при $1200-1500^{\circ} \mathrm{C}$ в вакууме или под давлением 6 ГПа (НРНТ) для отжига оптически активных дефектов, a также методом газоструйного CVD осаждения, стимулированного СВЧ плазмой [3]. Подложками для осаждения CVD пленок алмаза толщиной до 400 мкм являлись пластины кремния с $\mathrm{SiC}$ нанокристаллами для улучшения адгезии с плотностью от $10^{8}$ до $10^{10} \mathrm{~cm}^{-2}$ [4]. В зависимости от теплового бюджета и потока

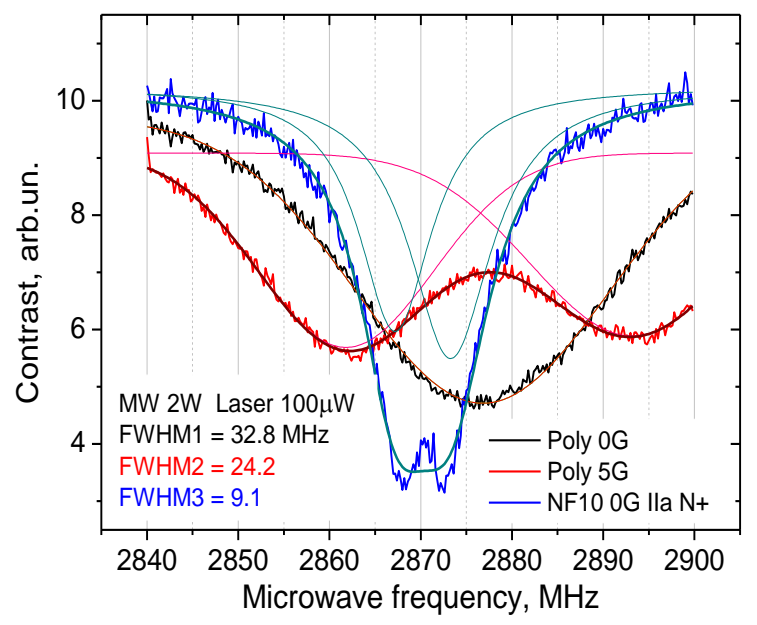
газов вырастали как отдельные нанокристаллы, так и поликристаллические пленки алмаза с размерами кристаллитов до 20 мкм и концентрацией $\mathrm{NV}$ центров до 1 ppm.

Алмазные наностолбы на монокристаллическом алмазе с 200 нм слоем NV центров создавались травлением сфокусированными пучками ионов галлия и последующим отжигом [5]. При максимальной температуре отжига $1500^{\circ} \mathrm{C}$ в вакууме никаких дефектов, кроме NV и $\mathrm{SiV}$ центров на уровне $\sim 1$ ppb нет. При НРНТ отжиге содержание NV центров в наноструктурах было $>0.2 \mathrm{ppm}$. Данные оптически детектируемого магнитного резонанса, измеренные при комнатной температуре (Рис.), показали, что монокристаллические наностолбы с NV центрами пригодны для высокочувствительной векторной магнитометрии с субмикронным разрешением, a поликристаллические слои алмаза с NV-центрами соответствуют требованиям, предъявляемым к высокотемпературным датчикам статических магнитных и тепловых полей.

Работа поддержана проектами РФФИ 18-29-19069 и 19-29-03031.

\section{Лumepamypa}

[1] J.F. Barry et al. // Rev. Mod. Phys. 92, 015004, 2020.

[2] T. Wolf, et al. // Phys. Rev. X. 5, 0410012015.

[3] A.K. Rebrov et al. // Interfacial Phenomena and Heat Transfer, 7(2), p. 131-137, 2019.

[4] V.P. Popov, et al. // Materials Today Communications, 28, 10249, 2021.

[5] S. Rubanov, et al. // Diamond and Related Materials, 63, p. 143-147, 2016. 